\title{
オージュボン傅と加茂市のオージュボン祭
}

Audubon's Biography and Audubon Festival

at Kamo-City, Niigata.

成 澤 多美也

Tamiya Narusawa

\section{Audubon の誕生}

John James Audubon（日本で怰オージュボンと垺びならされている が厂メリカ入にはオーダボンとい妨いと通じない。New Standard

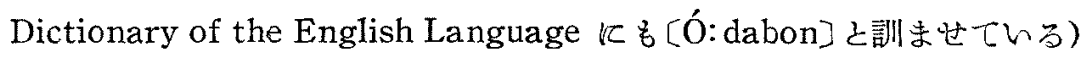
が死んだのは，1851年1月27日で，アメリカでは 1951 年盛な百年祭が催 された。目本ではまり有名でないためか当時少しもさかがれなかつた。私

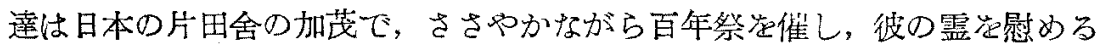

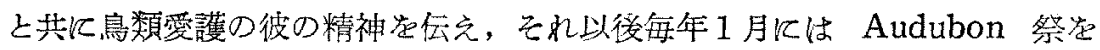
催している。

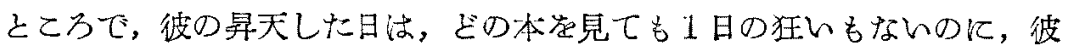
の生れた日, 場所, おどろいたことには彼泣産んだ父母ですら確然子かかつ ていない。彼が有名であるだけに，このことが今もつて話題に上り，研究の 対照になつて諸説紛々定まるところがなん。

生れた日についていうならば, Encyclopedia Britannicaでは1781 年と なつているが, 1937 年 Macmillan 社出版の Octavo 版 The Birds of

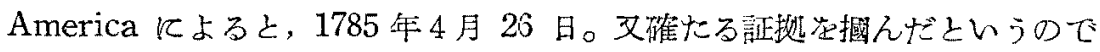
一部の信用定博している Francis Hobart Herrick 教授は 1785 年 4 月 22 日としている。

生れた場所も Haiti 島であつたり, Aux Cayoであつたり，Louisiana の Marigny 貴園等とされている。

Audubon の父とされている人沈フランス人 Howbeit Audubon で, 船 長ですつたため，普通 Captain Audubon と呼ばれているが，船乗だけに， 大西洋觉湖と心得，広く海外貿易にすたつていた。Santo Domingo（今の 


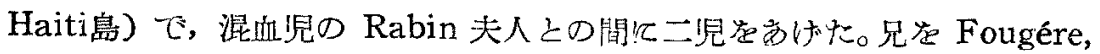
妹足 Muguet 々呼んだが，此の島沉暴動が起きて夫人は不虑の死农遂仿，

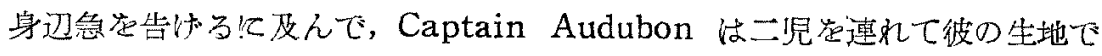
あるフランスの Nantes の町化逃㷌つた。その男の子が J.J. Audubon であるとんうのが Herrick 教授の説である。

Captain Audubon と Rabin 夫人との間男女の子供のあつたととは 認めても，て机がそのまま大きくなり J.J. Audubon になつたかぼうかと んうこと!てついては，贊成できないというのが一方の説で，この人達仕むし ろフランス革命で断頍台上の露と消えたブルボン王朝のルイ16甘とマリイ・ アントアネットとの閒出来た皇儲である之確信しているのである。ての皇

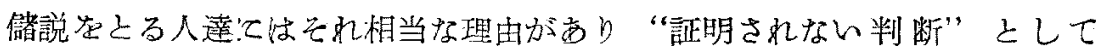
Herrick 教授の説得年傾けようとしない。

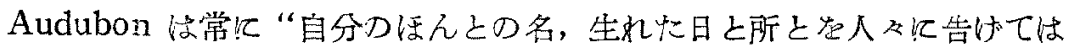
ならないと父からかたく禁じられている”と洩らしていたが，てれがそもと 吕紛紏の原因姿なしているのでする。とこふが彼の妻 Lucy は英国生れの しつかりしけ婦人て確証がない限り物事を易々之信じないたちであつたが，

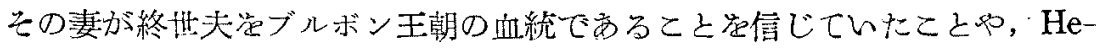

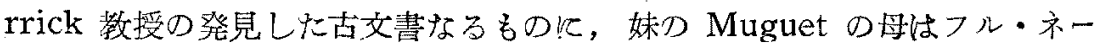
ムで登録されているてかかから机，J.J. Audubon の方は，父 Captain Audubonの名が記されていらだけで，何故か母の名は記されていなかりた

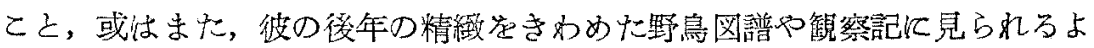
う異状な才能色もつていながら9才以前のこるは全く覚えていないという ことなどが皇储説在固執する人達にとつてヌとない有利な論颋となつている のである。

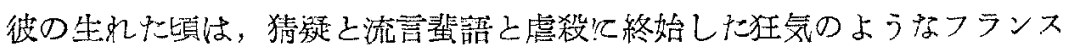
革命がゴッタ返えして居り，彼が此つ世军を出す時の濃霧であつたてとが

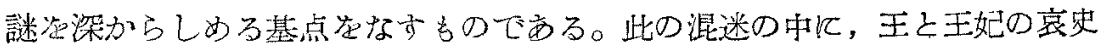

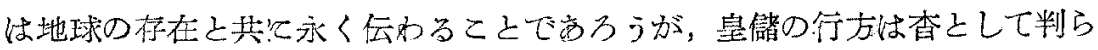

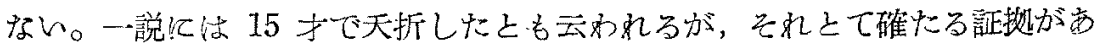
るかけではない。

当時 Captain Audubon の住んでいる地方は，王党派の労力の強いとこ 
ろで，多分王党派から低頼されて，同年毣の (Rabin との間沉出来市子共と

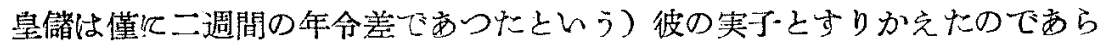
うというのが，皇储説を芰持する人達のがんとして譲らない点である。

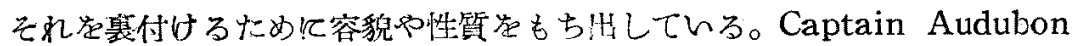

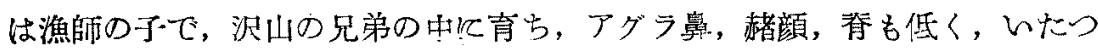
て風彩の上がらない人であった。J.J. Audubonは此々反対にいが各高貴 の生れで西ること思わせる風格具え，まだリイ・アントアネットが生

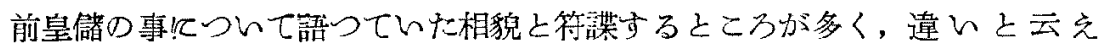

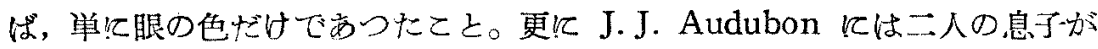
西つたが，何れも Captain Audubon にはは似亦，やはりさるやれでとなき 血筋をひいたのでないかと思わしめるものがあつた。彼が器用で西つたの方 ル1 16 世が，錠前造りという一国の帝王としてはまととれ似合わしからぬ 趣味の遗伝で西ろうと。

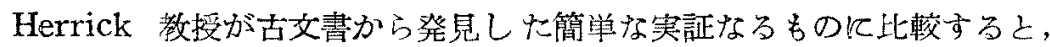

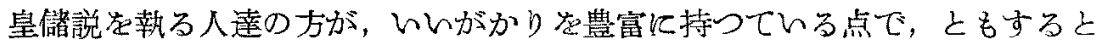

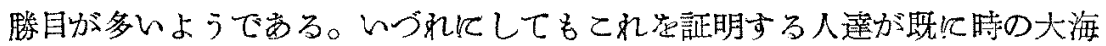
の中消えてしまつたこととて，何狆を正確とすることも出来ないし，㣬 が後年雄名をはせるようになつてから，彼の敵方が，彼を攻揧して云つた

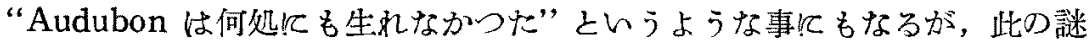
牥今後も永く論駁が繰りかえされることであらう。

\section{Audubon の渡米}

フランスで，彼は継母の手で充てられた。此の継母は実母以上に優しい人

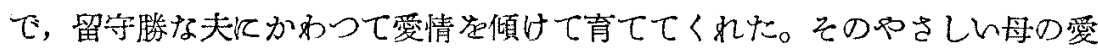
の中に，彼仗若草の上うに伸びていつた。彼の最も好んげのは，花や昆虫， 石や鳥で需つた。彼の小供部屋讷此青空学校から学びとつて来け教材でギ ッシリ詰められ，さ沶がら小供博物館の観が第つた。

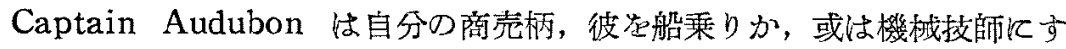
る樍りであつた。彼を Rochefort 兵学校!入れたのもをうした念愿からで

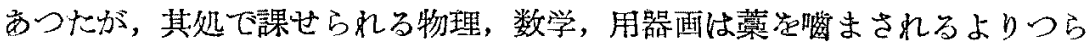
いちのであつた。居堪らなくなつて寄宿舍から脱走を企てて失敗し速れ戻さ 
れたが，父は彼在世界中で最も下手な船乘りにするよりは，彼の好む絵画で も学ばせようと, 当時その道では有名な巴里の Jacques Louis Davidの経 営する絵画学校比大学さ䜣たしかし只てで教六る絵画はおよそ生硬なもの ばかりで，彼の好きな鳥の美しさや，゚゚ちびちした生命の躍動等みじんもな かつた。更きたらない彼は僅か 2 年てして此の学校在見捨ててしまつた。彼 は籠定離れた小鳥のように再び青空学校官由な翼を伸ぱすことができた。 Captain Audubon は，此のような生活疾晔送らせて一生在台無しにして はという不安と，もう一つは，アメリカ亿買い求めて置いた広大な㖘場の管 理も人まかせでは心もとなからなので，1803年彼が 17 才の時单身アメリカ 飞渡航させてしまつた。その時の名前は Jean Jacques La Forét Au. dubon とフランス流によばれしていた。

彼の落らついたフィラデルヒヤの近郊 Mill Grove は彼にとつて，何の

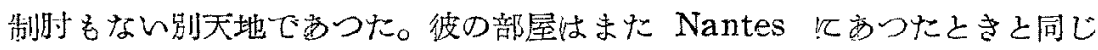
よう沉卵や舁か荅でぎつしりつまつてしまつた。

此処で彼は永年思的がらつていた野鳥指写の手法を夢で見ることができ

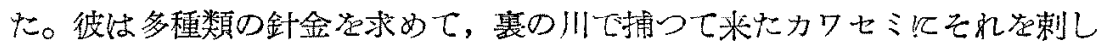

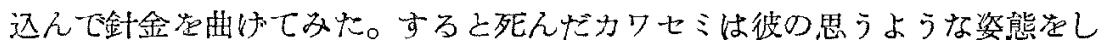

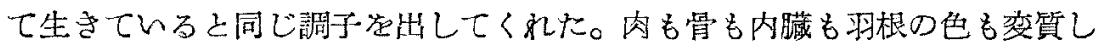

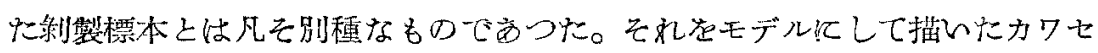
ミは今までのどの鳥の絵よりも真伅せまつていた。彼が啳年 The Birds of America 或は Viviparous Quadrupeds of North America 飞描々 た鳥や獸にもこの手法ととつたことは彩色する場合油絵具炎用いず，主とし て水彩とパステル【よつたてとと共に一つの特色としてあけられている。

彼は此処で，たまたま隣泪越して来た英国系の Bakewell 家上知り合 い，乙の長女 Lucy と想思の仰になり，結婚のゆるしを得るためフンンス

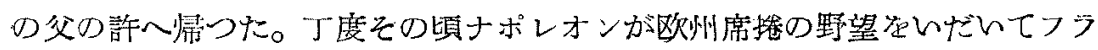

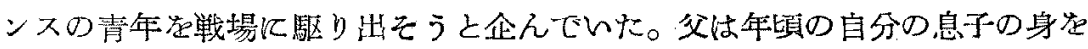
慮か心て, Ferdinand Rozier という手固い青年を一人雇つてアメリカ八 共飞帰すことにした。その時旅券に書かれた偽名が John James Audubon で，その後すつと此の名前が用いられるようになつた。

彼が St. Nazaire を出帆してから，海戝船に追し迴されたりして料肎に 
着いたのは 44 日目であつた。かくて Bakewell 氏の許しを受け1808 年 4 月5 日 Lucy と結婚することができたのは，彼が 23 才Lucy が 21 才の 時である。しかし此の二人の楽しかるべき航海は海賊て追いがられた以上 多難な風波が前途儿待つていたのである。翣 1809 年長男 Victor Gifford

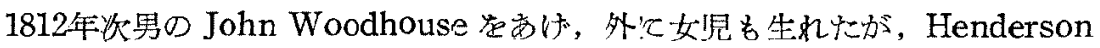

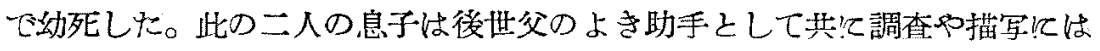
けみ立派な図版の出版をすることができた。

\section{Audubon の事業}

彼は小売商人でも亩り事業家でもあつた。しかし彼ほど失敗の連続をやつ た者は世にも珍しんであるう。

結婚前相談相手 Rozier 青年々経営した鉛鉱山は美事失敗して親譲りの財 産も殆どつかいつしてしまつた。

その後 Lucy の伯父の商事会社で見習奉公怘したが商才につんては無能 振りを遗憾なく発揮して，でよくことわられてしまつね。

1807年 Rozier 青年と Louisville でキャラコ, 茶, 砂糖, 弾薬の小売商

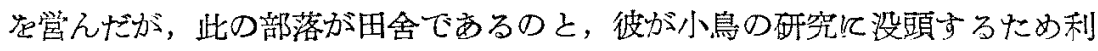
益壮少しもあがらなかつた。

1810年此処の店在たたんで Ohio 油の川下, Henderson に移つて同じ 小売商営んだ。競争相手が少いから售かるだ力うという目算ともう一つは 新しい鳥が見つかるかも知れないという二つの理由で。しかし此の村估当時 二百户足ら市の僻すうの土地であつたため，売れるものとては，少量の弾 薬, 羊毛製品, ウィスキー位のもので西つた。

その年の冬 St.Genevieve 移つた。乙の町で蛙商売も不振ですつたが，

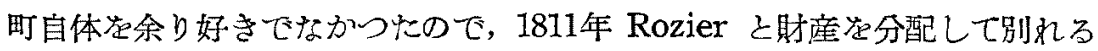
ことになつた。妻のいる Henderson まで165哩の道走歩いて帚つた。

Henderson で伎若い書毁 John Pope 友雇い入れたが, 彼と同趣味です

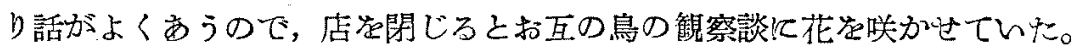
Pope はよく店の管理をしてくれたので，利益も西がり相当な暮し学するこ とができ，もともと派手好きな彼は家具調度も万端揃えるととが出来た。 こでは土地の売買在覚え，安く手て入れ高く売りつけた。そうした生活が 3 
〜 4年続くうちに足を抜くことの出来はい程深入りしていた。丁展その頃パ ニックが全米を吹きまくり銀行の破産が相ついで起きけ。彼の土地売筫業に も大きな手違がはじまり出した。

その前 New Orleans で Lucy の兄弟と協同出資でやつていた商会る此 のパニックのあ妾り灰食つて脆くも倒産してしまつた。

此の失敗をとり杘すけあに，製粉工場之製材工場を兼称た工場をはじめた が，金虐み出すべき工場は，彼の金やLucyの財産をどん欲に吸んてんで しまつケ。工場には彼の描いて鳥の絵が淋しく貼られていた。

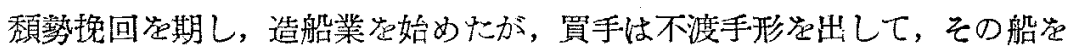
運転してミシシッピイ河穵下航してしまつた。此の悪らつな買手と大立ちま わりを演じ，相手炎七口で剌し，彼も棍棒でぶんなぐられててん倒してしま つた。载判所て㭔び出されて“相手方に致命的な負傷它させた人殺し一歩手 前の不㙁者”ときめつけられた。

一方製材所之製粉工場の倩権者が，彼て支払友請求してきたが，無一文の 彼はたまりかねて Louisville 『夜逃忙した。債権者は彼在捉之て投獄して しまつた。支払能力がないので, 結局破産の宣告在受けて辛うじて出獄した が，乙の時彼の手許に残つたものとては，妻子と猟銃，衣服之描きためた鳥 の絵だけであつた。流石沉此の時ばかりは鳥のとと考考方る気持が漂かない ほどですつた。

\section{The Birds of America 其他の出版}

彼が鳥の絵措描いていたのは，全く彼の趣味からで，自然の美に打たれ て，それ㾜もつ上身近なものKしたんという内的欲求によるものですつて出

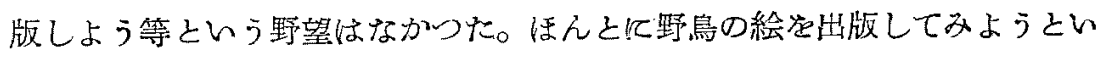
う気化なつたのは，1820年というから 35 才の眭で妻もこれには非常に乗り 気になつた。

1822年長男のVictor 在遇れて費府に向つて出発した。勿論大した旅費は

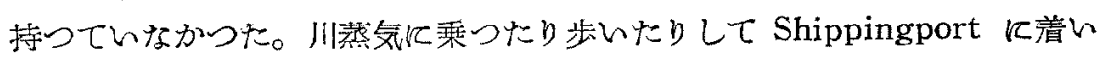
たときは慣中僅に 13 ドしかなかつたという。一冬ここで過して，敞像画

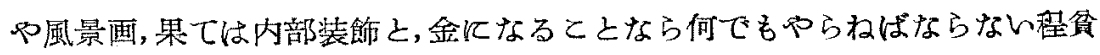
しかつた。翌年費府に出て有名な芸術家や科学者に遇うことができた。Th- 


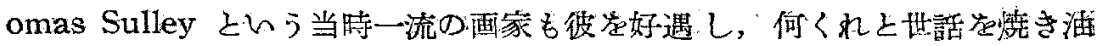

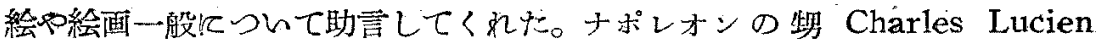

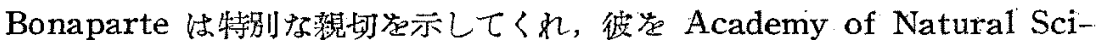
ences に紹介してくれもした。彼の絵は Academy に陳列され非常な賞潜

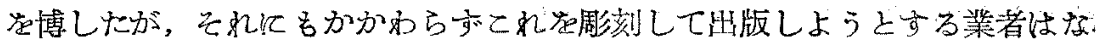

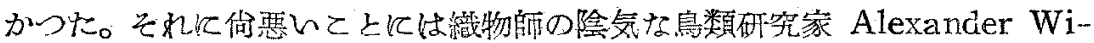

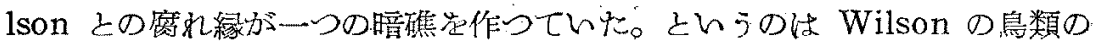

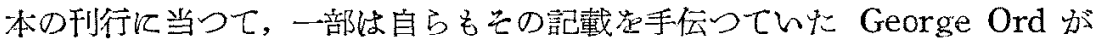

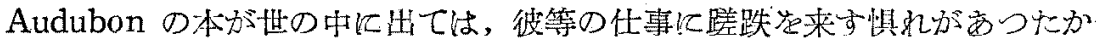

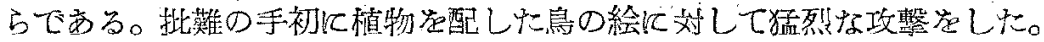

それやこれやで費府で出版するのぞみは全く水泡に帰してしまつだ。彼は 費府断念して New Yorkに出た。しかしここでも出版は思いもよらなか

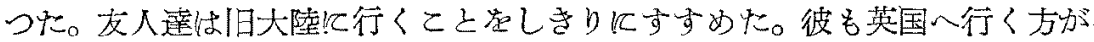
得策でないかと思つた。

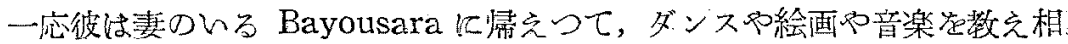

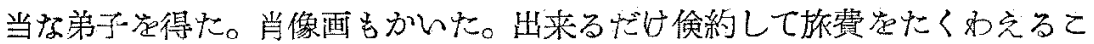
とにした。かくて 1826 年の春までに 400 以上の鳥の絵定描き，一年ほぼか

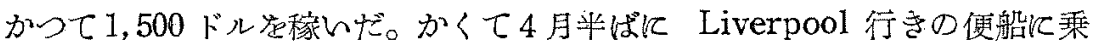
るととができた。

新大陸の珍しい鳥類，乙れ几植物や昆虫定配しただけでも充分人在ひきつ けるに足りるのであるが，彼の新しい手法や，鮮明な色彩，大胆な構図は芸

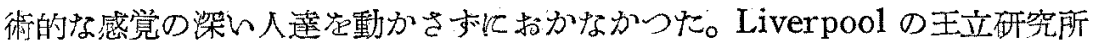
で展臨されると果然大きな反響在まき起した。牛津大学，劒橋大学でち手厚 く䒨迎され牛津大学図書館或は Liverpool 図書館などは，出版したら購人 しょうと公式《予的してくれた。London で彼の名は既によく知られて いた。殊飞当時社交界でち, 画壇でも有名な Thomas Lawrence 卿の知遇 をうけた。このために絵は高い洒格で売ねた。

Edinburg で W.H. Lizars という当時の彫刻師閒では一流の人物にす うことができた。Lizars は Audubonの絵を見て打たれると共に即時据刻 学ひきうけてくれた。1826年に结，彼の最も傑作と信じてい惟の七面鳥が 届けられた。大きさも彼が注文していたように Doubl Elephant Folio (27 
×40时)の大版であつた。此は当特の出版物としては最大のものであつた。 しかし不幸にす Lizars の図版エがストライキを起して僅に 10 図版を作つ ただけで中止せざるを得なかつた。

その後 Robert Havell を発見したのであるが, 此の人はまた若く, 社会 的にる余り知られていなかつたしかし腕はたしかで Lizars に四敵するも のがあつた。かくて 1827 年の終までに 5 部 25 図版を仕上げた。此の人は息 子と共同でやつていたが惜しくも 1830 年て他界しこの後息子が独力でやる ことになつた。

Audubon は彼の絵学一部5図版にして次々上予約者に渡すこよにしてい た。最初 300 部の予䄪者炭とる積りであつたが実際は 279 人の名を得た。も つとも 1838 年までて実祭残つたのは 125 人とも 161 人ともいわれている。 当時 1 部 ( 5 図版) 2 ギニイ, 全巻 87 部 435 図版で価格にすると, 182 ポ ンド, 14シリングであつた。

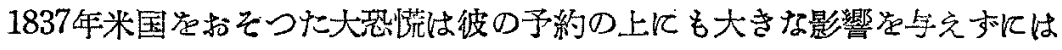

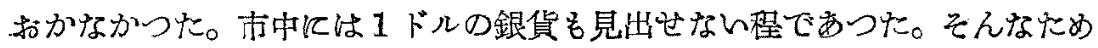

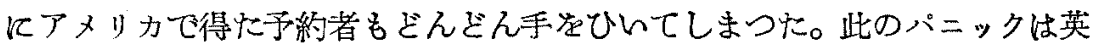

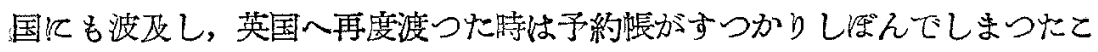
とに括どろんた。彼が Louisiana 出発してから 12 年目 1838 年 6 月 The Birds of America の最後の図版ができた。此の前後に Ornithological Biography 5 卷も完成してんた。

それより以前 1829 年 5 月家族を連れて英国加占米国一戻ると The Bir-

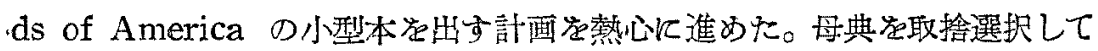
7 巻に收少 1829 1844 年に 1,000 部発行することができた。この中には母 典になかつた植物も新に加えたり 12 種の新種の鳥も入れ全部で500図版, テキストもつけ面目を一新した。世に Octavo 版と呼ばれているのがてれ で西る。乙の小型本には Victor と John の兄弟が助力している。

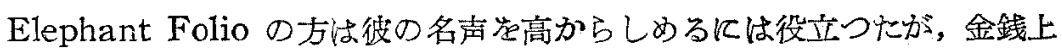
の報酬は殆どなかつたととろが此の小型本の方は低庵なため誰からも買い したわれ，そのために一策は相当な収入をすけるこができな。

此等の図版は分類学的な配列ではない。また中には幼鳥と成鳥との区別な 誤つて幼鳥の力新種としたものがある。Bald Eagle の幼鳥在Washing- 
ton Sea-Eagle とした如きである。Cuvier's Regulus は果してこうした 鳥が実在しただろうか，或は単に彼の記憶のみによつて描かれたのではいか

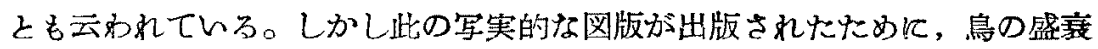
が明になつたことは特筆すべきてとで㐫る。たとえば当時その数の莫大なて とに於いて有名であつ Passenger Pigeon の如きは Alexander Wilson の測定によると一群 22 億 3027 万 2 千, 彼自身の測定によると 11 憶

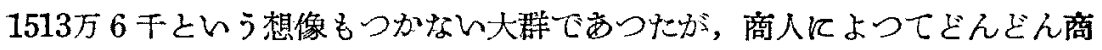
品化され 19 世紀には一日に何千バーレルも方場に出倚されたなめこの数を 減じ，1914年僅て 1 羽残つた最後の鳥がシンシナーチ動物園で死んで名実共 亿絶滅してしまつた。

Great Auk の如きも食糧や羽毛足得万ため濫獲され，次第に云の数㾜減 じ，1844年 Iceland で，1848年 Norway で，1870年 Newfoundland で 夫み一羽すっとれているが，その後誰の手にもとられていない。

Reddish Egret の如きも羽毛商に追い迴わされて Florida 地方からは 姿走消してしまつた。Whooping Crane 4 Hudson 湾から Iowa 飞わ たつて広く分布していたが，今僅に 20 羽ぐらんしか残つていないといかれ ている。同じょうな運命に西るものに Prairie Chicken, Ivory-Billed Woodpecker（これ最近また発見されたといわ机ている）或住 Carolina Paroquet 等少西る。

また当時乞の数が少がつた Meadow Larkの如きは，今全米何処へ行つ ても見ることが出来るようになつた。一眭絶滅しかけたため Audubon 協会

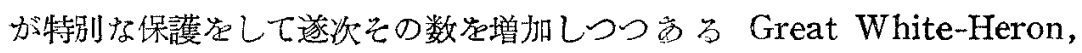
Laughing Gull, Roseate Spoonbill 等恓る。

この様に鳥の消息がよくかかる点に大きな貢献起たばかりでなく，鳥に

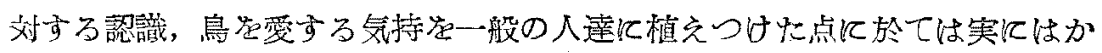
り知れない大きは貢献ということができる。

小型本の刊行方順調沉す」ものをみて，乙の監督をJohn に委せ 1843 年 に新しい計画宝すすていた。それは哺乳動物の図鑑を出すととで西つた。 脕年彼は New York飞 30 エーカーの土地實つて Minnie's Land と呼び

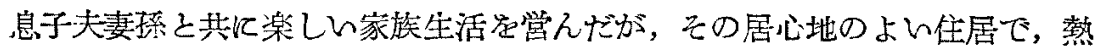
心に哺乳動物を研究していた。友人にとれ等の䅺本の送付走依頼し，殊に親 
友 Bachman には邆虑なく頼んでやつたし，自分もミズーリ河在遡上して 調查沉要たつた。

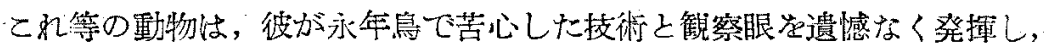

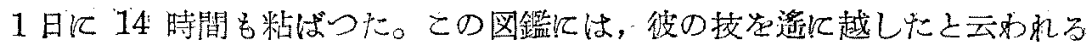

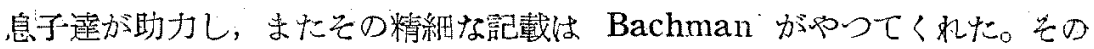

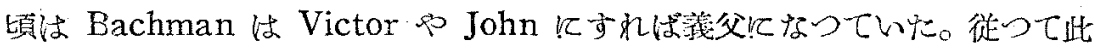
の本恃 Audubon 全家族の共同作品であるというととができる。此の動物 の本架有名蛙 Viviparous Quadrupeds of North America で市るが, 完

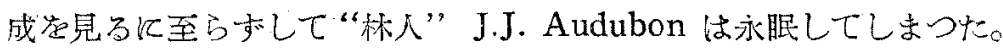

しかし，水彩々パステルて描かれ视躍動的な一一余りに劇的だとる云わ礼

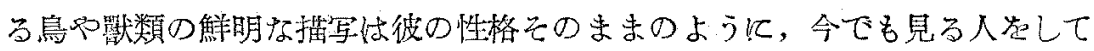

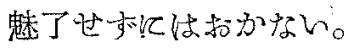

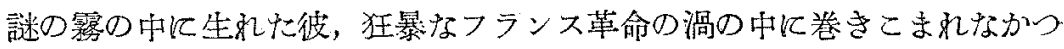

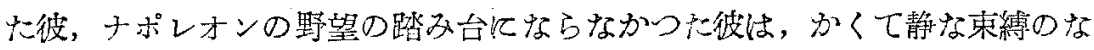
い目由な青空の中で，若竹のように伸び，死んではえの愛の地下菜が，広く 世界の隅ふにまで伸びてとしている。

\section{V 晚年及び死後の㮡譽}

精敉な躍動的なとして色彩に富九だ鳥の描写は，新大陸ではもて辢されな かつたが、ひとれび英国汇渡ると俄然人ふの注目の的汇なり，学会でる高く 評洒するようになつた。彼の図版に结 John J. Audubon 或は J.J. Audu-

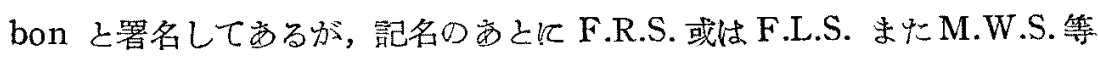
のアブリビエイションが西る。

F.R.S. 或は F.R.S's. L \& E 或は F.R.S.E. は王立科学拹会々員 Fellow of the Royal Societies London \& Edinburg の路。

F.L.S. 将有名なりニウス会員て Fellow of the Linnean \& Zoological Societies of London.

A.A.A.S. 壮アメリカ科学芸術協会の䀩で American Academy of Arts and Sciences. Edward Everett 飞推されたるので苛る。

此の外巴里の博物学会の会員 Member of the Natural History Society of Paris 飞推され，紐育のリシウム学会の会員 Member of the Ly- 
ceum of New York 等多数著名な学会の会員㐳推されるに至つた。

てれ等のうち彼の最も名誉としたのは王空学会の会員とリニウス学会で受

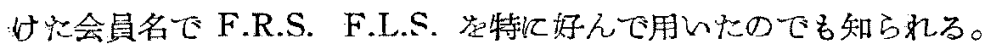

彼の死传の人気がまけ大したものでする。彼の名学等した地名，建造物，

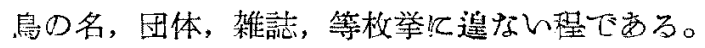

晚年伎は一家と共に New York に暮し, そこで逝去したが New York 大学では，彼の功績在れた之て 1900 年大学構内にある“名䇾の殿堂”に彼

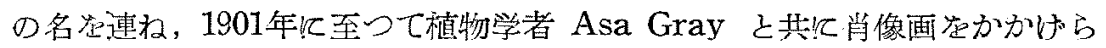
狆当光栄に浴した。こえて 1927 年 A. Stirling Calder が彫刻しな彼の胸 像汃同し䍙営で除幕されろに至つた。

彼の名に规てでつけた Audubon Mountain というのが Denver 市北 方 40 哩 Colorado 山系にする。栖高は 13,223 呎でミズーリ河水亲の水

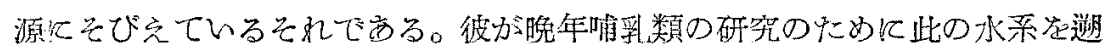

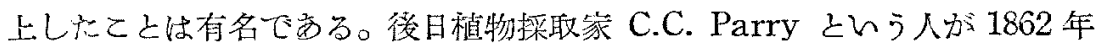

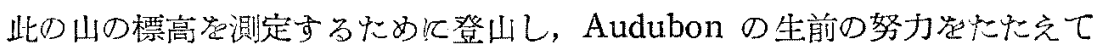
命名したといわれている。しかも此の山住んでいる二種の鳥も彼の名定冠 している。ウグイス科の Audubon Warbler, もう一つはッグミ科の Audubon's Hermit-thrush でする。

Henderson の町情上は因縁淺からぬものがある。苦難の恃代最も永く

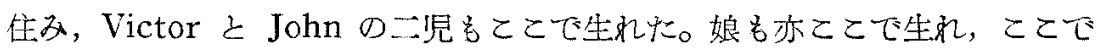

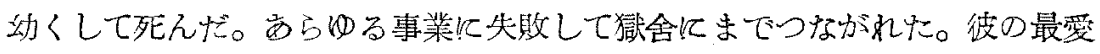
の妻 Lucy は Audubon の死後ここに移り住み，ここで死んだという。彼 としては悲しんがしかしなつかしん想い出の土地でする。従つてここては彼 の名左冠したところが多い。街の名でAudubon Street. 数会に Audubon Church, 学校当 Audubon School というの肪る。公園では彼の名觉 つけたものが三つも奇る。Audubon Mill Park, Kentucky 州立の Audubon Memorial Park, も う一つは500 エーカー程する森林で Audubon Park というのがあるが，此の公園の中には Audubon 博物館がある。彼 の生洼の事蹟全部集結したところで, 古風なフランス風に建てられている

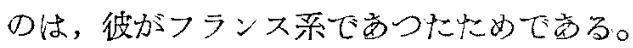

此の公園の附近には龙大な経責で作られたという Audubon Memorial 


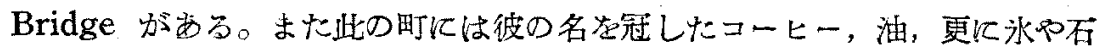
宸に何の關係があつたのか矢張り彼の名前がつけてする。

野鳥研究雑誌 Bird Lore が Audubon Magazine と改称された。その

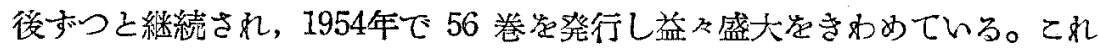
発行する拹会蚛 Audubon Society であるが, Audubon Magazine 以 外飞数種の定期雑誌が発行されている。単江雑誌発行だけでなく野外研究活 動が非常に活潑で Audubon Nature Camp 走もち青少年は勿論成人のた めにも毎シーズン探鳥，植物，屁虫採取等が催されている。

Audubon よりるもつ之文化的偉大な功績をあけ中人があつた。しかし Audubon 程アメリカ人の人気等博している人は他に例睍ない。何故なの で西ろう。

彼がともするとブルボン王朝の皇儲であつたかるしれないためであるう か。可らゆ事業に失敗したてとが今もつて人の同情を惹いているのであう

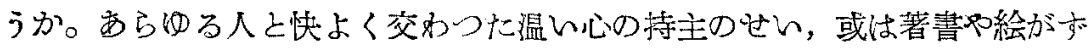

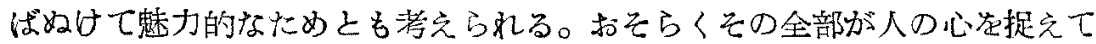
いるのであろうがえれにもましてわ礼われの看過できないことは，よるべな

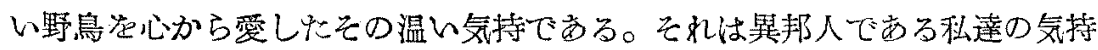

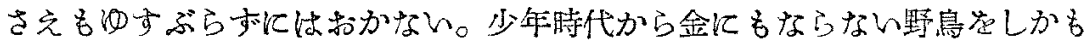

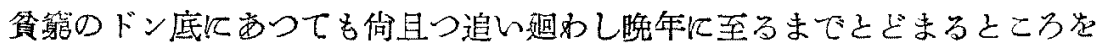
知らなかつたその熱情こそは誰の心先も動かすもので西る。

\section{VI 加茂の Audubon 祭}

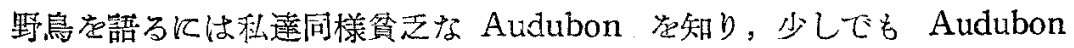
の精神空伀えたいという気持に駆られる。早い話がアメリカの野鳥愛好熱方

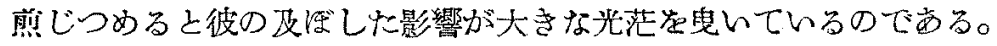

1951年怡彼の百年忌であつた。夏ては西つたが，私遟は彼の百年祭をささ やが町の図書館で催した。背まつたのは僅に2 30名ですつた。次の年は 1 月 27 日で此の時は 60 名であつた。第 3 回目は 1 月 27 日の命日が普通 の曜日だつたのて 1 月 31 日儿催し 200 名の参会者ですた。今年は第 4 回 目远1月24日に催し 350 名が集まつた。

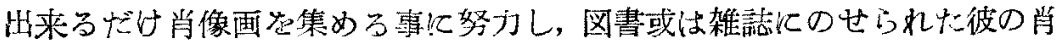


像は洩らさ才蒠集し，私の学校の須藤教諭，田中画伯等に依頼したり，私自 身幾晚もかかつて描き上げ炕のが写真に見るような彼の肖像である。右から 左の順で示すと，

1) Audubon の胸像。New York 大学の“聖なる殿堂”《㚣置さ礼てい るもの。

2) Cruickshank の筆によるもの。1937年 Macmillan 会社発行の Audubon's Birds of America 所揭

3）1824年彼が 39 才の折 Mississippi 河下流の探鳥後 Louisiana 在訪 れケ際の自画像。油絵で㐫ることも有名である。

4) 次子 John Woodhouse が 1841 年に描いたもので American Museum of Natural History 所蔵のちの。原画はこの外に愛大, 乗馬が 配してある。

5) Henry Inman 筆。American Engraving Society で出版した The Birds of America D口絵所揭。

9）1848年頃 Brady という人が初めてとつた銀板写真で，最もよく彼の 相貌在伀えたもので㐫る。

祭壇には此の肖像画をかかけ両側花瓶がおかれる。一つは加茂中学の

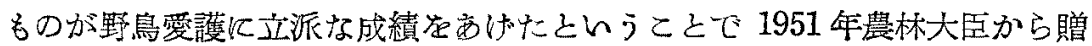
られたもので西る。う一つは私の学校が全国十校の一つに選ばれ，てれま た農林大臣から表彰された名誉西るちので日本でさえあまり知られていな い私邆の小さな町に二つも大臣賞が来ているところは珍しいととである。こ れも Audubonの括がで方ると思つている。

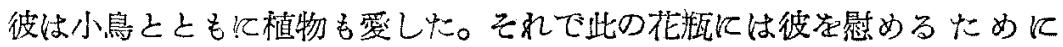
美しい温室咲きの花学捙すととにしている。

彼は酒がきらいであつた。だからきつと怙草子が好きだつけに違いない ということで, 真中にはお菓子共える。滆草を Indian から習い覚えて 親友の Bachman にもすすめる程好きだつたので㖶草㥕供えることにして レる。

此の日は特舞踊起催すととにしている。二つの小学校の女生徒がやつ てくれるのであるが，子供好きであつた Audubon も然悦んでくれること であうう。 
その外 Audubonの話，野鳥の話，或いは柍西军写したりする。

寒々北国の此の町ては，1月末といえば筜がさんさんと降つているが会 場の中心温い零国気に包まれ集まつて来た少年少女は等しく煩在真赤江火

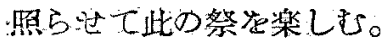

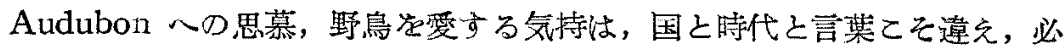

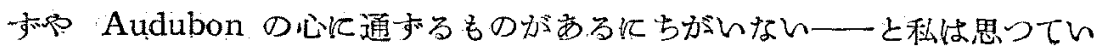
る。

(1954年4月 22 日，筆者は新潟県立加茂農林高等学校教諭)

\section{國立自然教育園について}

The National Garden for Nature Study and its History

\section{鶴 田 総一郎}

\section{Sōichiro Tsuruta}

今から湫 550 年前, 南朝の雑出楖下上総之助がー-族を伴つて武蔵野に下り, その原始林の一角に居堂定めたのが国立自然教育園のそもそもの扣てりで西

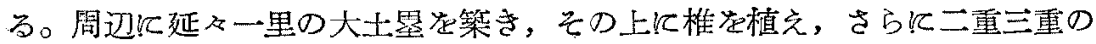

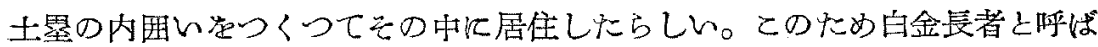
れた。これが江戸のはじめに四国高松の藩主松平濽岐守の下屋敷となり，明 治年間中は陸海軍の火薬庫及び衣料做になつていたが，元の廃止ととるに大 正 6 年当時の宫内省に献上されて白金御料地と改まり，この終戦まで続いて レたのである。

この荒筋の歴史でるわかる通り，本園はほとんぼ人工の加わらない中世の 武蔵野の大自然林の面影危そのままとどめている。また地形の变化に富み，

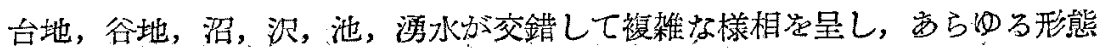
の自然環境に总まれているといつても過言てはない。従つて生物相も豊かで 高等植物 (羊歯植物以上) 約 1,000 種, 昆虫的 5,000 種が発㫕され，野生鳥類 
Vol. XIII, Pl. XVII 第 13 巻第 17 図版
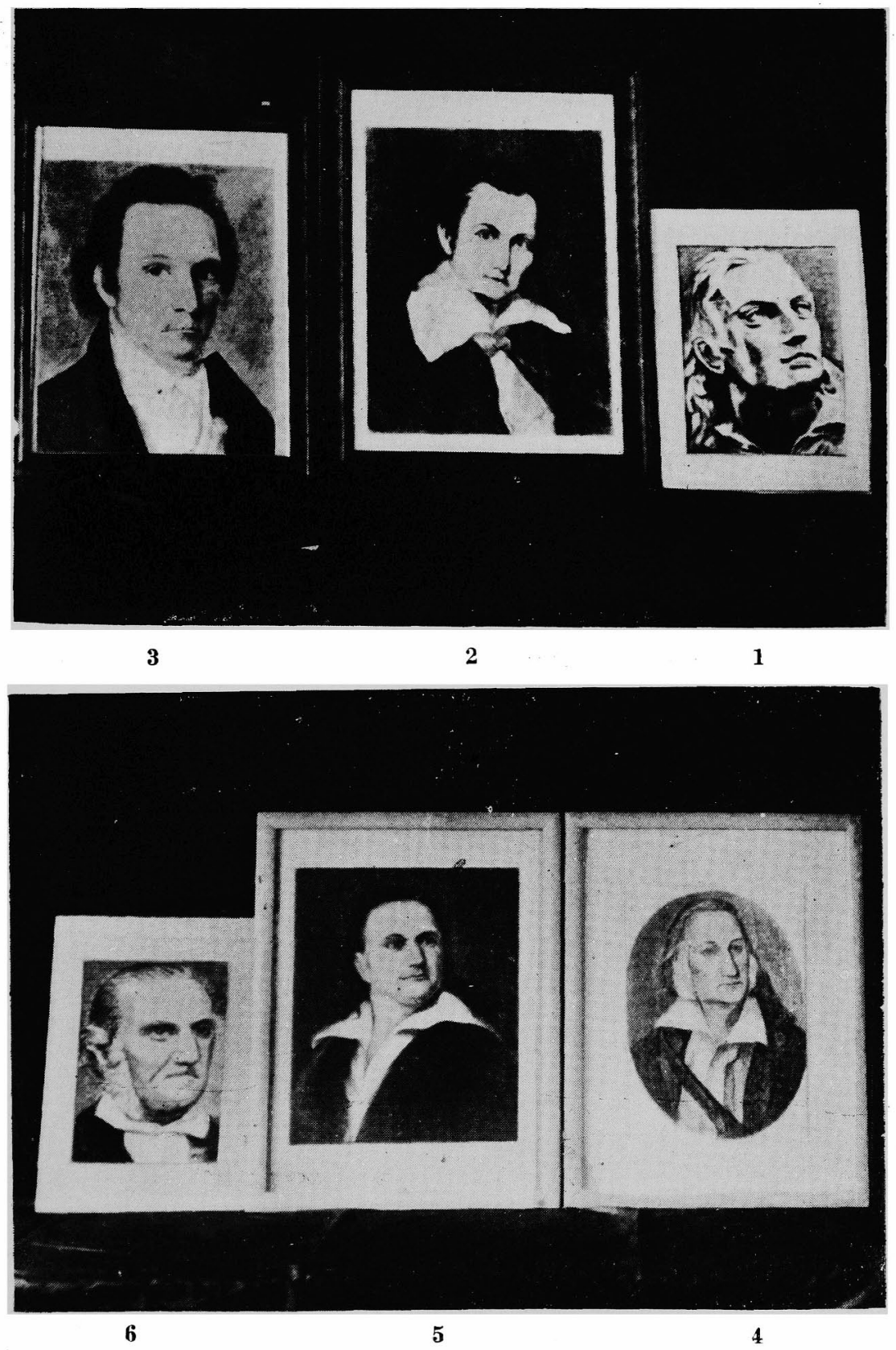

オージュボンの肖像 （本交70頁説明参照） 
Vol. XIII, P1. XVIII

第 13 卷 第 18 困版

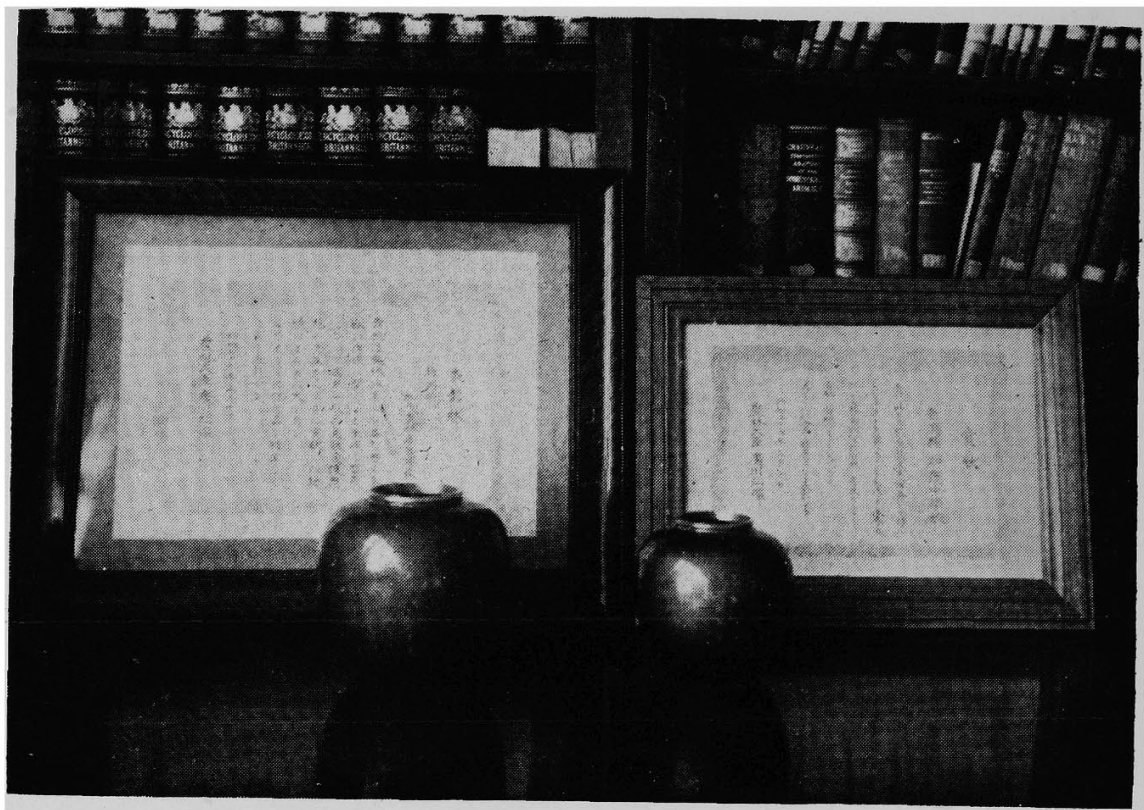

野鳥愛護の办に上つてら汁た農林大至賞。右が加茂中学校のもの, 左が加茂㖘林 高等学校のもの（本交70頁参照）

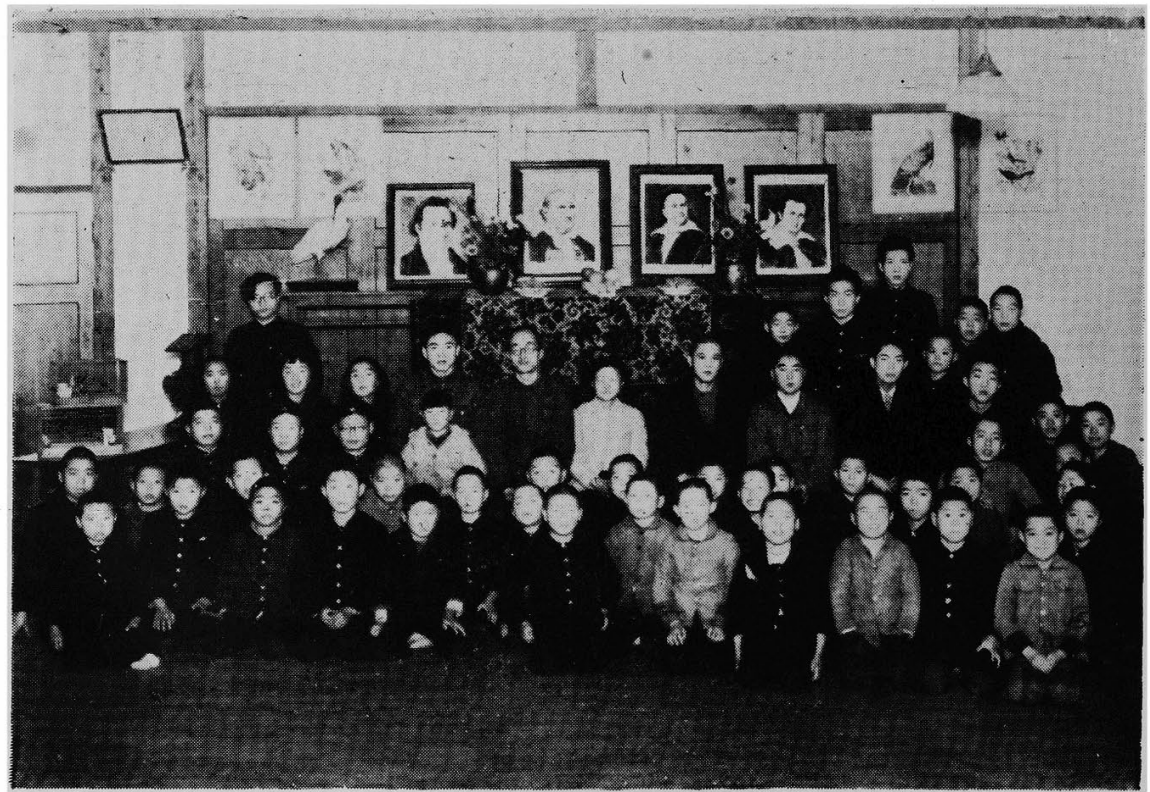

加茂市の第二回オージュボン祭，1952 年 1 月 27 日(本沃69真参照) 